\title{
Analysis on Sentence Pattern of Spanish in Teaching - Classification of Simple Sentences
}

Kaiwen Lou

Shandong Vocational University of Foreign Affairs, Jinan 250000, Shandong, China

Email: 369252808@qq.com

Abstract: This paper mainly expounds the ways for analysis of five types of simple sentences and two kinds of special sentence patterns.

Keywords: Spanish, syntax, simple sentences

\section{Introduction}

In spite of the presence of various expressions in the Spanish language, the frame structure of each sentence is generally fixed, which can be conducted for analysis. The author give a lecture on analysis of sentence patterns of the Spanish based on the experience in the teaching for students to explain sentence structure. I am privileged to have the senior colleagues for rectification of any mistakes in this paper.

Sentence patterns in Spanish can be divided into two categories: Simple sentences and compound sentences. A simple sentence is one with only one subject-predicate structure. Compound sentences consist of two or more simple sentences. As two simple sentences (or more than two simple sentences) are combined in different ways, as a result, compound sentences can be divided into compound complex sentences and subject-subordinate clause.

\section{The five basic sentence patterns of simple sentences}

In teaching of Spanish, all simple sentences can basically divided into six parts as sujeto, perdicado, complemento $\mathrm{u}$ objeto, atributo, modificativo and complemento. Among them, subject, predicate and object constitute the main part of the sentence. The three components of atributo, modificativo and complemento are the complementary components of a sentence. Their presence or absence show no effect on the integrity of the sentence. As there is only one subject-predicate structure in simple sentences, we can say that a simple sentence has but one conjugated verb.

(Note: We refer it conjugated verbs rather than verbs. Verbs can take the form of infinitive verbs. or gerundio, and there can be more than one in a simple sentence, while conjugated verbs imply that there can be only one subject-predicate structures)

In the teaching process, we will divide simple sentences into the following five types of structures while explaining sentence patterns to students:

(1) Subject and predicate

(2) Subject, predicate and object

(3) Subject, predicate and double objects

(4) Subject-predicate-object complement

(5) Subject-link verb-predicative structure

Let's take a look at five types of sentence patterns one by one:

\section{1 "Subject-predicate" structure}

Subject-predicate based sentences consist of subject and predicate. The predicate of the sentence is usually intransitivo. For example:

(1) Yo salgo.

(2) Elena saltó de algría.

(3) Vamos a la biblioteca a estudiar.

In the above mentioned examples (1), salir is an intransitive word with no object followed after. The sentence consists of the subject yo and the predicate salgo, which Is a typical subject-predicate structure.

The subject in the example (2) is Elena and the predicate verb is saltar. The following de algría is a complement to give supplementary explanation of the reason why Elena jumped-Happiness.

In the example (3), the subject is "nosotros" (Judged by the conjugated verb vamos). Vamos (ir) is an intransitive verb 
without object followed after. The a la biblioteca is adverbial clauses of place. A. estudiar is adverbs of purpose.

\section{2 "Subject-predicate-object" structure}

A subject-predicate-object structure consists of a subject, a predicate and a direct object. The predicate must be transitivo as:

(1) Estudiamos español.

(2) Ana tiene muchas amigas.

(3) Puedes salir ya.

(4) Carlos dice lo mismo.

In the first sentence, estudiamos is an conjugated verb. We infer from the inflection of the suffix that the subject is nosotros and the verb estudiamos followed by español is the direct object. ) The definition of direct object: The first undertaker of an action by Gilligaya in Advanced Course in Spanish Grammar, 1979, Pg 68). In 1.1(3), estudiar is not followed by direct object and is an intransitive verb. A large number of Spanish words enjoy the characteristics of both transitivo and intransitivo. The criterion for judging whether it is a transitive verb is whether it has a direct object.

In the second sentence, Ana is the subject, tiene is the predicate verb, amigas is the object, and the adjective modifies amigas, which can be said that "muchas amigas" is the direct object of the sentence.

In the third sentence, it is inferred from the verb puedes that the subject is tú. While, the object is the infinitivo salir. In Spanish, infinitive verbs have the nature of nouns and can replace nominal in sentences, such as subject, object, etc.

In the fourth sentence, Carlos is the subject, dice is the predicate verb and lo mismo is the direct object.

Sometimes, the direct object can also be a sentence. For example, we can change the previous sentence to:

(5) Carlos dice que mañana no llueve.

The italic part of the sentence replaced lo mismo in the original sentenc, served as the direct object of the verb dice. This substitution of direct object is called a direct object clause.

As the direct object clause is a declarative sentence, que can be used such as the example(5).

When the clause is a general question clause, si (which means"whether or not") can be used to introduce the clause. For example:

(6) Me preguntan si puedo venir mañana.

When the clause is a special question clause, we use the special question word or question phrase as the leading word of the clause. For example:

(7) Quiero saber quién está cantando.

In this sentence, the special interrogative pronoun quien acts as a conjunction between the main clause "quiero saber" and the subordinate clause "quién está cantando".

\section{3 "Subject-predicate double object" structure}

This type of sentence pattern consists of subject, predicate, direct object and indirect object. The predicate must be transitivo. For example:

(1) Pásame el libro, por favor.

(2) Le presento a mis amigos.

(3) Escribo una carta a la embajada.

In the three sentences, the italic part is the direct object and the underlined part is the indirect object. The indirect object is either a person or an anthropomorphic object (in example (3), the indirect object is "a la embajada", though it is still specific to write to someone in the a la embajada). And the direct object could be either a person or an object. Therefore, in the actual teaching process, we teach students to distinguish between direct object (objeto directo OD) and indirect object (objeto indrecto hereinafter referred to as OI), and we can say that if one is a person and the other is an object, then the person is $\mathrm{OI}$ and the object is OD.

\section{4 "Subject-predicate-object complement" structure}

This type of sentence pattern consists of subject, predicate, object and complement. The complement in Spanish is called adverbials in Chinese and English, which are used to explain the way of action, time and places and others. Complement is also divided into complemento circunstancial and suplemento. Note: Actually, direct and indirect objects are also called complemento directo and complemento indirecto respectively in Spanish. For example:

(1) Lo escribe con esta pluma.

(2) Me alegro de conocerte.

(3) Luis salió muy enojado.

In example (3), the complemento circunstancial muy enojado modifies both the verb salio and the subject Luis. This 
complement is called a double complement.

Complements can be nouns, infinitive verbs, or sentences. A sentence with an alternative complement part is called a complement clause. For example:

(4) Me alegro de que vuelvas.

In (4), que vuelvas ("you're back") replaces the incised complement of the original verb conocerte in (2), and is known as an incised complement clause (also known as a collocative complement clause in some grammarbooks).

In general, there are many types of complement clauses, which can be divided into nominal clauses and adverb clauses.

Noun clauses mainly include: Suplemento, direct object clauses, indirect object clauses, noun complement clauses and adjective complement clauses.

Adverb clauses (adverbial clauses): Adverbial clauses of time, adverbial clauses of place, adverbial clauses of cause, adverbial clauses of condition, adverbial clauses of concession, adverbial clauses of purpose, adverbial clauses of manner, adverbial clauses of result.

Since there are many kinds of complement clauses, we will not give redundant explanation one by one, which can be elaborates in the clause explanation part.

\section{5 "Subject-linking verb-subject structure"}

A sentence with subject-linking verb-subject structure consists of a subject, a linking verb and a predicate. This type of sentence is also called a noun predicate sentence. In Spanish noun predicates, we use tying verbs to link the subject to the predicate noun or adjective adverb. Unlike English, which has only one linking verb, be, Spanish has two linking verbs: ser and estar. When we use it, we need to choose one of them as a tying verb to connect the subject with the predicate. This is a difficult point in Spanish learning. Many linguists also argue over the selection criteria. Below we list some commonly used discrimination criteria.

\subsubsection{Logic-semantic analysis method}

In practical use, native English speakers are prone to be confused by two linking verbs. Chinese students show better performance in this regard. In traditional Spanish teaching, "we generally use logic-semantic analysis, thinking that ser is used to show inherent or permanent properties of things, while esta refers to those occasional and temporary states." (Dong Yansheng, 1999, Spanish Grammar, PAGE. 132) Most Chinese students can distinguish most of the semantics in basic Spanish through semantic-logical analysis. For example:

(1) Pedro es camarero.

(2) Pedro está enfermo.

However, some students are trapped in the wrong direction, thinking that ser represents a long period of time, while estar represents a state of short time. This mechanical, dogmatic cognition is far from the real meaning of estar and ser. For example:

(3) Pedro fue camarero en tres días.

(4) Pedro está enfermo durante todo el verano.

From the examples (3) and (4), we can see that the duration of time is not the criterion to measure ser and estar. The key is to see whether the predicate followed is to display the property or a state.

In addition, in many cases, some adjectives can be regarded to show both properties and states. They can be paired with ser and estar. But it means something different. For example:

(5) Luis es Listo.

(6) Luis esta Listo.

From the above four examples, we can see that adjectives, when combined with ser and estar, show different semantic meanings and have different emphasis. This point should be explained and summarized with the students in the teaching. Give the students a list of these adjectives. Ask the students to be careful not to confuse the meaning when translating.

However, semantic-logical analysis also has its drawbacks. The idiomatic usage of some adjectives does not conform to a logical-semantic analysis. For example:

(7) Pablo está muerto.

(8) La niña está viva.

Being "alive" or "dead" is the equivalent to a state of normality. However, Spanish uses estar to connect subject and predicate, which does not conform to logic-semantic analysis. Therefore, we should draw lessons from the research methods of distributivism and functionalism proposed by some linguists, supplemented by logic-semantic analysis.

\subsubsection{Overlapping distribution of ser and estar}

Ser and estar, as combined with the same group of adjectives, show no effect on the meaning of the adjective itself (as in 1.5.1.5-1.5.1.8). For example: 
(1) Eres alto.

(2) Estás alto.

(3) Ana es guapa.

(4) Ana siempre está guapa.

When ser is used, alto or guapa is seen as inherent characteristics of the subject. As estar is used, it shows the result after the subject experiences changes. In Chinese, it can be translated as: You are taller or Ana has become beautiful after dressed up.

\subsubsection{Differences between ser and estar}

a. Estar +adj. is equivalent to Volverse +adj or ponerse+adj. While, ser can't be replaced by these two structures. For example:

(1) Luis está algre. = Luis se pone alegre.

(2) Pablo está gordo. = Pablo se vuelve gordo.

If we say Luis es Alegre, it means "Luis is optimistic, which give attention to Luis's own personality. Pablo es Gordo. means that "Pablo is fat."These two sentences cannot equal to Luis se Pone Alegre and Pablo se vuelve Gordo. because changes can't be shown in the verb ser.

b. There is also difference between ser+p.p. and estar+p.p.

The past participle (infinpio pasivo for short p.p. ) in Spanish can be used as adj and functions as a predicative for a sentence. The ser+p.p. form is called the passive voice.

The grammatical structure of the passive voice is influenced by English. and por alguien can be added at the end of the sentence, which is similar to be+p.p. +by sb structure.

The form of estar+p.p. is the native Grammar of Spanish. with por alguien prohibited to be added at the end of a sentence.

For example:

(1) La ventana fue abierta (por Pedro).

(2) La ventana estaba abierta.

In Example (1), "La ventana fue abierta (por Pedro)" is narrating the action of Pedro. The sentence (2) is describing a state and the result of an action. This is one of the differences between ser and estarr and p.p.

In addition, because of the above properties, ser+ p.p. is generally used in the perfect tense, while estar+ p.p. Will appear in the imperfect tense. But the imperfect verb p.p. and ser are not subject to this restriction. For example:

(3) La novela es muy conocida por todos.

c. There is difference between adjectives matched with ser and estar.

According to teacher Dong Yansheng, most adjectives with ser are derived from nouns and can be called "nominal adjectives". For example, capaz-capacidad. While, estar is usually accompanied by participles of verbs, which can be called "verbal adjectives", e.g. harto-hartarse. (Spanish Grammar Law, 1999, 139-140)

\section{Oración impersonal and self-complex passive sentences}

The reason why the author does not list it together with the above five types of sentences is that in the actual teaching process of Spanish, the textbook usually lists the oración impersonal separately. Students can identify the oración impersonal by its symbolic words. There is no need to teach students along with the five sentence patterns above in case of confusion.

\subsection{Oración impersonal}

In the author's opinion, oración impersonal can be divided into the following two categories:

\subsubsection{The verb itself has no person}

A typical example of a verb that has no person is haber (hay).

For example:

(1) En la sala hay dos sillas y una mesa.

Hay itself is a conjugative verb with no person, which does not belong to any of the six nominative personal pronouns (yo, tú, él/ella/usted, nosotros/tras, vosotros/tras, ellos/ellas/ustedes).

In other words, the third person singular corresponds to an conjugated verb that acts as an impersonal conjugation. For example poder(puede), hacer(hace):

(2) Puede que nunca sepamos la verdad.

(3) Hace sol.

In example 2.1.1.1, although the subject of the Chinese sentence is "we", in the original Spanish sentence, "we" is the 
subject of the object clause. Puede is an conjugation of the third person singular, but the subject is not el /ella/usted. There is no subject in this sentence.

Hacer as a transitive verb means "to do". But when it means weather or time, it becomes an impersonal verb. There is not any real meaning just as an auxiliary verb.

\subsubsection{The subject of the sentence denotes a general reference}

We can use this type of impersonal sentence when the subject of the sentence does not refer to a specific person but to a general one, or when the speaker considers the subject unimportant. This type of sentence is not limited to the meaning of the verb, most verbs can apply this pattern. There are two specific forms:
a. Se + The third person singular conjugation
b. Third person plural conjugation
For example:
(1) ¿Se puede pasar por aquí?
(2) ¿Pueden pasar por aquí?
(3) Se nos invita a cenar, ¿quieres ir?
(4) Nos invitan a cenar, ¿quieres ir?

\subsection{Self-complex passive sentences}

Self-complex passive sentences are a big category in Spanish, which are often used in daily spoken Spanish. Although the word "passive" is shown, it is classified as "voz media" rather than "voz pasiva" (passive sentence), in the grammar teaching section of Modern Spanish. Voz media is consisted of the following elements:

(1) Surface subject is the deep object of the verb;

For example:

Desde aquí se puede ver toda la ciudad.

"toda la ciudad" is the object of "ver".

(2) The agent is often implied, which can also be introduced by prepositions.

For example:

Se venden muchas comidas en este supermercado.

"muchas comidas" is the object of "venden"."en este supermercado" can also be understood as "este supermercado", which serves as the subject. The sentence can be translated as "This supermarket sells a lot of food".

(3) The structure is: se+ third person conjugated verb. Whether the conjugation verb is singular or plural depends on the subject.

For example:

Note: In example 2.2.1, the structure of "se puede" is the same as that in example 2.1.2.1. However, one of the two sentences is self-complex passive and the other is impersonal. The biggest difference between the two is that the selfcomplex passive sentence has a clear subject, while the impersonal sentence does not. In 2.2.1, the subject is "toda la ciudad" (the whole city). While, in 2.1.2.1, there displays no subject. You can say that the subject does not exist, or that it is generic (can people pass through this place?).

Similarly, in 2.2.2, the subject of the sentence is muchas comidas, which is of plural form, so the predicate of the sentence venden is plural in the third person. As there is no subject in the impersonal sentence, the conjugation of the verb can only strictly follow the two forms of the sentence pattern and not be changed by other factors.

\section{Conclusion}

The author analyzes and summarizes the syntactic structure of Spanish and discusses its sentence structure and semantic features. The above mentioned sentence patterns cover most of the types of sentence patterns that students will encounter when learning Spanish. The study and practice for analysis of sentence pattern can contribute to reading, understanding and translating long and difficult sentences in Spanish, and thus improving the efficiency of learning sentence patterns of Spanish. The author summarizes the above teaching experience for mutual encouragement.

\section{References}

[1] Dong Yansheng. Spanish Grammar[M]. Beijing: Foreign Language Teaching and Research Press, 1999.

[2] Sun Yizhen. New Practical Grammar of Spanish[M]. Shanghai Foreign Language Education Press, 2010. 